\title{
PENGEMBANGAN MEDIA KOMIK PADA MATERI KEANEKARAGAMAN HAYATI BAGI SISWA KELAS X SMA
}

\author{
Ana Mandasari ${ }^{1)}$, Mariani Natalina L ${ }^{2)}$, Nursal $^{3)}$ \\ Email: anamandasaril6@gmail.com. \\ ${ }^{122) 3)}$ Program Studi Pendidikan Biologi, FKIP Universitas Riau
}

\begin{abstract}
This study aims to produce comic media on biodiversity lesson for class X senior high school students. This research was conducted at the Faculty of Teacher Training and Education Riau University, Public Senior High School 8 Pekanbaru and Public Senior High School 6 Pekanbaru in November-February 2021. The type of research used is Research and Development (R\&D) with the ADDIE research model consisting of 5 stages, namely analysis, design, development, implementation and evaluation. In this research, it is limited only to the development stage. Data collection instruments in the form of validation sheets and questionnaires of respondents. The results of the validation of comics media on biodiversity lesson for students of class $\mathrm{X}$ senior high school are at an average value of 3,60 with a very valid category. The result of the limited test score are 3,42 with a very good category. Thus, comics on biodiversity material for students of class $\mathrm{X}$ of senior high school have been successfully developed with very good quality and can be implemented on a wider scale.
\end{abstract}

Keywords: Development , Comic, Biodiversity

\section{PENDAHULUAN}

Perkembangan ilmu pengetahuan dan teknologi sangat berpengaruh terhadap masyarakat di era globalisasi. Pada era ini setiap individu dituntut mampu mengembangkan potensi yang ada pada dirinya untuk bersaing ditingkat nasional maupun internasional. Salah satu upaya yang dapat dilakukan untuk menghadapi era ini adalah dengan meningkatkan kualitas pendidikan. Pendidikan merupakan hal yang terpenting dalam setiap individu dan merupakan aspek terciptanya sumber daya manusia yang berkualitas. Untuk mewujudkan hal tersebut diperlukan upaya yang efektif, salah satunya dengan melakukan pengembangan kecakapan hidup abad ke-21 yaitu kemampuan literasi sains pada peserta didik. Pesatnya kemajuan ilmu pengetahuan dan teknologi, harus diimbangi dengan pemahaman peserta didik dalam berinteraksi terhadap ilmu pengetahuan dan teknologi, yaitu dengan bersikap bijak dan mampu beradaptasi terhadap sains, lingkungan, masyarakat dan teknologi. Tujuan dari pendidikan sains yaitu agar peserta didik mampu memahami konsep sains dan perkembangannya pada peristiwa alam yang terjadi di sekitarnya, sehingga diharapkan peserta didik dapat menggunakan teknologi untuk memecahkan masalah dalam kehidupan sehari-hari atau literasi sains.

Literasi merupakan kemampuan peserta didik dalam membaca, menulis, dan berkomunikasi melalui kegiatan yang memiliki dinamika dan perubahan secara cepat kemudian menanggapinya secara luas dalam aspek sosial dan ekonomi (Tang, 2015). Faktanya saat ini budaya literasi di Indonesia masih sangat rendah, yang tercermin pada perilaku peserta didik yang tidak mau membaca bila gurunya tidak menyuruh mereka membaca. Hal tersebut sejalan dengan hasil survey yang dilakukan di sekolah, menunjukkan bahwa peserta didik memang tidak mau membaca apabila tidak disuruh oleh guru. Hasil studi PISA 2018 yang dirilis oleh OECD menunjukkan bahwa kemampuan peserta didik Indonesia dalam membaca, meraih skor rata-rata yakni 371, dengan ratarata skor OECD yakni 487. Kategori kemampuan membaca peserta didik Indonesia berada diperingkat 72 dari 77 negara, skor sains anak Indonesia ada di peringkat 70 dari 78 negara dengan 
skor rata-rata 396 (OECD, 2019). UNESCO menyebutkan Indonesia urutan kedua dari bawah soal literasi dunia. Menurut data UNESCO, minat baca masyarakat Indonesia sangat memprihatinkan, hanya $0,001 \%$. Artinya, dari 1.000 orang Indonesia, cuma 1 orang yang rajin membaca (Wiedarti et al., 2016).

Hasil analisis soal PISA 2015, salah satu tema dan indikator esensial PISA yaitu materi Biologi SMA kelas $\mathrm{X}$ pada tema keanekaragaman hayati. Materi keanekaragaman hayati merupakan materi yang objek belajarnya sangat luas. Objek yang menjadi bahan kajiannya merupakan hal-hal yang sering dijumpai di kehidupan nyata sehingga perlu cara pembelajaran yang tepat untuk memahamkan peserta didik (Fitria, 2017). Materi keanekaragaman hayati mencakup tingkat keanekaragaman hayati dari tingkat gen sampai tingkat ekosistem, keanekaragaman hayati Indonesia dan manfaat keanekaragaman hayati. Berdasarkan cakupan materi tersebut, peserta didik dituntut untuk mampu memahami konsep daripada hanya sekedar menghafal (Maxtuti et al., 2013). Memahami konsep materi keanekaragaman hayati sangat penting, sehingga untuk memahami materi keanekaragaman hayati diperlukan banyak contohcontoh gambar yang tidak bisa dilihat secara langsung oleh peserta didik.

Salah satu faktor yang memengaruhi rendahnya literasi sains peserta didik adalah pemilihan media pembelajaran. Kehadiran media dalam pembelajaran dapat memotivasi peserta didik dalam belajar dan penggunaan media pembelajaran dapat lebih bermakna yakni pembelajaran bukan hanya meningkatkan penambahan informasi tetapi dapat meningkatkan kemampuan peserta didik untuk menganalisis dan mencipta (Sanjaya, 2014). Banyak bentuk media yang dapat dijumpai untuk mendukung suatu proses belajar peserta didik, salah satunya adalah media komik. Menurut Maxtuti et al. (2013), komik dapat menjadi variasi media di masa depan karena perpaduan kalimat narasi, susunan teknik sastra gambar dan warna, serta teknik pengambilan foto disatukan dalam satu media. Selain itu, media komik juga mendukung terbentuknya proses belajar yang menyenangkan dengan menciptakan suatu respon positif peserta didik. Komik mempunyai potensi besar sebagai media pembelajaran. Perpaduan gambar dan teks dapat meningkatkan pemahaman peserta didik akan konsep yang dipelajari.

Melalui bimbingan guru, komik dapat berfungsi sebagai jembatan untuk menumbuhkan minat baca sesuai dengan taraf berpikir peserta didik, yang akhirnya dapat pula meningkatkan motivasi belajar. Komik keanekaragaman hayati tersusun dengan rangkaian kata berbentuk narasi, gambar dan foto-foto sehingga konsep materi keanekargaman hayati tersampaikan dengan baik, mudah dipahami, dapat menjadi sumber belajar dalam menciptakan suatu variasi belajar, serta dapat meningkatkan minat baca peserta didik.

\section{METODE PENELITIAN}

Penelitian ini dilaksanakan di tiga lokasi yaitu, Fakultas Keguruan dan Ilmu Pendidikan Biologi Universitas Riau, SMAN 8 Pekanbaru dan di SMAN 6 Pekanbaru. Tahap pertama adalah validasi komik yang dilakukan oleh empat orang validator yaitu dosen Pendidikan Biologi Fakultas Keguruan dan Ilmu Pendidikan (FKIP) Universitas Riau, guru Biologi di SMAN 8 Pekanbaru dan guru Biologi di SMAN 6 Pekanbaru. Selanjutnya uji coba terbatas tahap I dan tahap 2 dilaksanakan secara daring (dalam jaringan) menggunakan media online yang dilaksanakan di rumah masingmasing mahasiswa dan peserta didik yang disebabkan oleh adanya pandemi COVID-19. Waktu penelitian dimulai pada bulan November 2020-Februari 2021. Rancangan penelitian yang digunakan peneliti mengacu pada model pengembangan ADDIE yang terdiri dari 5 tahapan yakni Analisis (Analysis), Desain (Design), Pengembangan (Development), Implementasi (Implementation), dan Evaluasi (Evaluation). Penelitian yang dilakukan peneliti hanya pada tahap analisis, desain, dan pengembangan. Berikut merupakan langkah-langkah pengembangan komik berbasis literasi sains pada materi keanekaragaman hayati bagi siswa kelas X SMA: Penelitian ini diawali dengan tahap analisis, yaitu analisis hasil PISA, analisis kurikulum dan analisis materi 
pembelajaran. Semua tahapan analisis yang dilakukan akan menghasilkan tujuan pembelajaran mengenai materi keanekaragaman hayati pada mata pembelajaran Biologi di SMA.

Tahap desain, peneliti membuat suatu rancangan komik. Peneliti tidak hanya merancang pengembangan pada komik saja pada tahap ini, melainkan juga merancang silabus dan Rencana Pelaksanaan Pembelajaran (RPP) yang digunakan sebagai acuan dalam pembuatan komik yang dikembangkan. Komik yang dikembangkan terdiri dari 3 pertemuan dengan sub materi yang berbeda-beda, yaitu keanekaragaman hayati tingkat gen, jenis dan ekosistem, keanekaragaman hayati di Indonesia dan pemanfaatan keanekaragaman hayati di Indonesia, penyebab hilangnya keanekaragaman hayati dan upaya pelestarian keanekaragaman hayati.

Tahap pengembangan adalah tahap dimana seluruh rancangan (desain) yang telah dibuat dikembangkan oleh peneliti. Silabus pada KD keanekaragaman hayati dibuat sesuai dengan format rancangan silabus. Setiap pertemuan pada masing-masing KD dikembangkan Rencana Pelaksanaan Pembelajaran (RPP) sesuai dengan format RPP yang telah dirancang. Kemudian dikembangkan komik sesuai dengan format komik yang telah dikembangkan.

Teknik analisis data dilakukan secara deskriptif kualitatif dan deskriftif kuantitatif. Analisis deskriptif kualitatif dilakukan dengan mengelompokkan informasi-informasi dari data kualitatif yang berupa masukan, kritik, dan saran perbaikan yang terdapat pada lembar validasi dan angket, sedangkan teknik analisis deskriptif kuantitatif dilakukan dengan mendeskripsikan angka skala 1-4 yang didapat dari hasil validasi maupun uji coba terbatas tahap I dan II dengan rumus sebagai berikut :

$$
\mathrm{M}=\frac{\sum F X}{N}
$$

Keterangan :

$\mathrm{M}$ = Rata-rata skor

$F X=$ Skor yang diperoleh

$\mathrm{N}=$ Jumlah komponen yang validasi

Adapun kriteria menghitung validasi berada di antara nilai $3.25<\mathrm{x}<4$ dengan kategori sangat valid, $2.5 \leq \mathrm{x}<3.25$ dengan kategori valid, $1.75 \leq \mathrm{x}<2.5$ dengan kategori kurang valid serta $1 \leq \mathrm{x}<1.75$ dengan kategori tidak valid. Sementara itu, untuk kriteria uji coba terbatas menggunakan penilaian dengan rentang angka yang sama namun kategorinya menjadi sangat baik, baik, kurang baik dan tidak baik.

\section{HASIL DAN PEMBAHASAN}

\section{Validitas Pengembangan Media Komik pada Materi Keanekaragaman Hayati bagi Siswa Kelas X SMA}

Lembar validasi digunakan untuk menilai tingkat kevalidan komik yang diberikan oleh validator. Cara menentukan kualitas komik yang dikembangkan adalah dengan menjumlahkan hasil rerata validasi dan uji coba terbatas. Pada saat validasi dilakukan penilaian dengan menggunakan 4 aspek, yaitu aspek kelayakan isi, aspek Bahasa/komunikasi, aspek penyajian dan desain, dan aspek manfaat/kegunaan. Hasil rerata dari 3 pertemuan produk komik yang divalidasi secara ringkas dapat dilihat pada tabel 1. 
Tabel 1. Hasil Validasi Ketiga Produk Komik

\begin{tabular}{cccc}
\hline No & Aspek & Rerata & Kriteria \\
& & & Validasi \\
\hline $\mathbf{1}$ & Aspek Kelayakan Isi & 3,69 & $\mathrm{SV}$ \\
$\mathbf{2}$ & Aspek Bahasa/Komunikasi & 3,58 & $\mathrm{SV}$ \\
$\mathbf{3}$ & Aspek Penyajiandan Desain & 3,61 & $\mathrm{SV}$ \\
$\mathbf{4}$ & Aspek Manfaat/Kegunaan & 3,55 & $\mathrm{SV}$ \\
\hline & Rata-rata & $\mathbf{3 , 6 0}$ & $\mathbf{S V}$ \\
\hline & Keterangan & $\mathbf{S V}$ & \\
\hline
\end{tabular}

Ket: SV = Sangat Valid

Aspek dengan nilai tertinggi berada pada angka 3.69, yaitu aspek kelayakan isi. Aspek ini mendapatkan nilai tertinggi karena komik memuat kesesuaian isi komik dengan Kompetensi Dasar dan tujuan pembelajaran, kebenaran konsep ditinjau dari aspek keilmuan, keruntutan materi dan ketepatan dialog cerita dengan materi keanekaragaman hayati. Pemaparan Kompetensi Dasar dan tujuan pembelajaran didalam media komik bertujuan untuk melihat ketercapaian kompetensi dari materi keanekaragaman hayati yang sedang dipelajari. Melalui KD dan tujuan pembelajaran di dalam media komik diharapkan peserta didik dapat mengetahui sub-sub materi yang akan dipelajari pada pertemuan tersebut sehingga pembelajaran lebih terarah. Komik ini juga disusun secara teratur dan terarah supaya konsep materi keanekaragaman hayati dapat tersalurkan dengan mudah dan cepat dipahami peserta didik. Materi pada media komik keanekaragaman hayati ini juga menggunakan referensi buku-buku pengetahuan yang berbasis kurikulum 2013 sehingga konsepkonsep materi keanekaragaman hayati yang ada didalam komik ini kebenarannya tidak diragukan lagi dan juga telah melewati hasil validasi oleh ahli materi.

Aspek sangat valid tertinggi kedua adalah aspek penyajian dan desain dengan perolehan skor 3.61. Media komik ini dibuat dengan teratur dimana memiliki gambar, warna, dan bentuk huruf yang menarik serta penyajian tokoh pada komik proposional. Bersifat proposional berarti komik mampu membuat pembaca terlibat secara emosional dalam membaca komik. Tokoh pada komik yang proposional adalah memiliki komposisi bentuk dan ukuran yang seimbang yaitu tidak ada gambar yang terlalu besar dan terlalu kecil. Pada aspek penyajian dan desain juga memadukan foto dan gambar sebagai proses penyampaian materi keanekaragaman hayati. Hal ini didukung oleh Arsyad (2014) yaitu menyatakan bahwa media visual yang baik adalah media yang dapat menyampaikan pesan secara jelas dan mengefektifkan penggunaan bahan visual seperti gambar dan foto yang disajikan dengan menarik. Contoh komik menampilkan gambar dan foto yang menarik dapat dilihat pada gambar berikut.

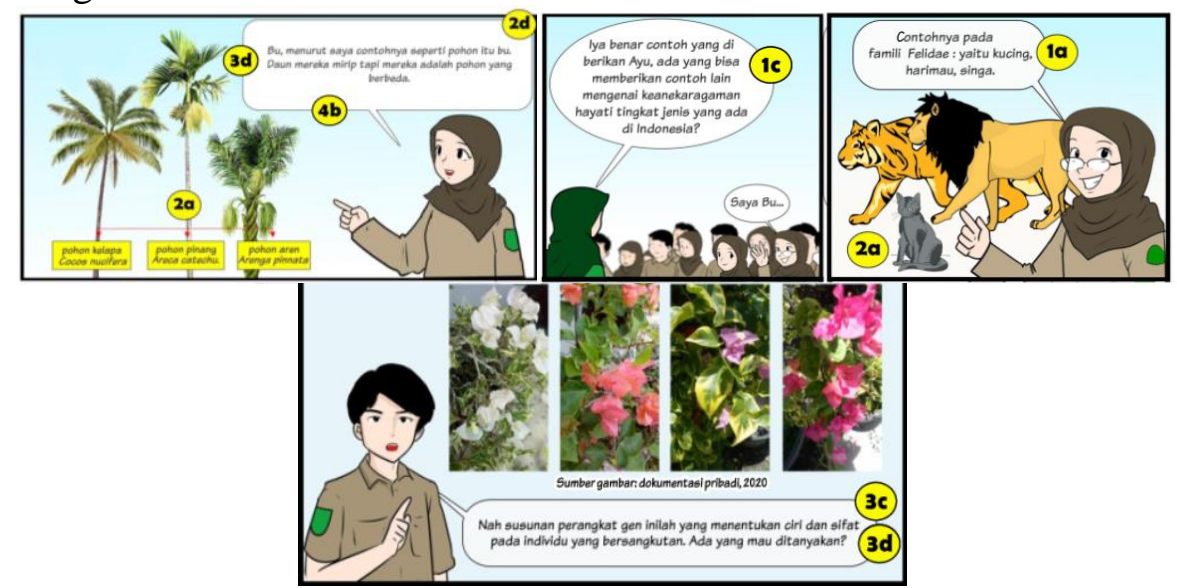

Gambar 1. Komik menampilkan gambar dan foto yang menarik 
Aspek sangat valid tertinggi ketiga adalah aspek bahasa/komunikasi dengan perolehan skor 3,58. Aspek bahasa merupakan sarana (alat komunikasi) penyajian dan penyampaian informasi/pesan. Bahasa yang digunakan didalam media komik ini disajikan dengan menggunakan bahasa yang sederhana dan mudah dipahami peserta didik. Hal ini didukung oleh pernyataan Purwanto (2013) bahwa kalimat atau kata-kata dalam bahasa komik dibuat sesederhana mungkin, ringkas, jelas dan padat, sehingga mudah untuk dipahami.

Aspek sangat valid tertinggi keempat adalah aspek manfaat/kegunaan dengan perolehan skor 3,55. Aspek manfaat/kegunaan merupakan penilaian terhadap kebergunaan media komik sebagai media pembelajaran. Salah satu manfaat media komik ini yaitu merupakan salah satu bentuk sumber belajar yang dapat membantu peserta didik dalam kegiatan pembelajaran. Komik ini juga dapat digunakan dalam proses pembelajaran dua arah yaitu sebagai alat bantu mengajar dan sebagai media pembelajaran yang dapat digunakan sendiri oleh peserta didik. Dalam berbagai hal, komik dapat diterapkan untuk menyampaikan pesan dalam berbagai ilmu pengetahuan, dan karena penampilannya yang menarik, format dalam komik ini seringkali diberikan penjelasan yang sungguh-sungguh bukan hanya sekedar hiburan saja (Jariah, 2017).

\section{Hasil Uji Coba Terbatas Media Komik pada Materi Keanekaragaman Hayati bagi Siswa Kelas X SMA}

Setelah produk komik divalidasi, selanjutnya dilakukan revisi untuk memperoleh komik yang siap dilanjutkan ke tahap uji coba terbatas. Uji coba terbatas yang dilakukan peneliti terdiri dari uji coba terbatas tahap I kepada mahasiswa pendidikan biologi semester 3 sebanyak 15 orang, kemudian uji coba terbatas tahap II yang dilakukan kepada peserta didik SMAN 6 Pekanbaru kelas X.7 sebanyak 32 orang. Hasil ujji coba terbatas tersebut dapat dilihat pada tabel berikut.

Tabel 2. Hasil Uji Coba Terbatas Produk Komik

\begin{tabular}{lcccc}
\hline Aspek & $\begin{array}{c}\text { Uji Coba } \\
\text { Tahap I }\end{array}$ & $\begin{array}{c}\text { Uji Coba } \\
\text { Tahap II }\end{array}$ & Rerata & Ket \\
\hline Aspek Penyajian & 3,51 & 3,32 & 3,42 & SB \\
Aspek Kebahasaan & 3,46 & 3,37 & 3,42 & SB \\
Aspek Tampilan Menyeluruh & 3,48 & 3,40 & 3,44 & SB \\
\hline Rerata & 3,47 & 3,36 & $\mathbf{3 , 4 2}$ & SB \\
\hline
\end{tabular}

Ket: SB = Sangat Baik

Berdasarkan hasil yang diperoleh, terlihat bahwa aspek tampilan menyeluruh komik mendapatkan nilai paling tinggi yaitu 3,44 dengan kategori sangat baik. Aspek ini merupakan kategori sangat baik karena media komik pada materi keanekaragaman hayati yang dikembangkan menampilkan halaman sampul dan chapter komik yang memiliki gambar, warna dan bentuk huruf yang menarik serta tampilan gambar dan warnanya dapat memicu minat belajar. Hal ini sesuai dengan kesan mahasiswa setelah membaca komik yaitu "Komiknya sangat menarik, dengan adanya gambar dan warna meningkatkan minat saya untuk membaca serta dapat memahami materi secara ringkas dari komik yg disajikan". Didukung oleh pernyataan Puspitorini (2014) yaitu menyatakan bahwa komik sains merupakan salah satu alternatif media bermain sambil belajar. Pemberian pengalaman pengalaman belajar yang menyenangkan dapat meningkatkan hasil belajar peserta didik.

Aspek penyajian dan bahasa juga mendapatkan nilai yang tinggi, yaitu 3,42 dengan kategori sangat baik. Tingkat skor pada aspek penyajian dapat digunakan untuk melihat kesesuaian antara materi yang disajikan pada media komik yang dikembangkan dengan Kompetensi Dasar dan 
Indikator Pencapaian Kompetensi pada setiap pertemuan. Materi yang dikembangkan yaitu materi keanekaragaman hayati yang terdiri dari 3 pertemuan. Pertemuan 1 membahas mengenai keanekaragaman hayati tingkat gen, jenis dan ekosistem. Pertemuan 2 membahas mengenai keanekaragaman hayati di Indonesia baik flora maupun fauna serta penyebarannya berdasarkan garis Wallace dan Weber, serta membahas mengenai pemanfaatan keanekaragaman hayati. Pada pertemuan 3 membahas penyebab hilangnya keanekaragaman hayati dan upaya pelestarian keanekaragaman hayati. Skor yang diperoleh pada aspek 1 ini menandakan bahwa isi komik sudah sesuai dengan Kompetensi Dasar (KD), Indikator Pencapaian Kompetensi (IPK) dan tujuan pembelajaran setiap pertemuan. Media komik dirancang dengan merujuk kepada Silabus dan RPP yang telah dibuat sebelumnya agar komik menjadi sebuah media edukatif yang dapat menyampaikan pesan sesuai dengan Indikator Pencapaian Kompetensi (IPK) dan tujuan pembelajaran materi keanekaragaman hayati. Hal ini sesuai dengan kesan mahasiswa terhadap komik ini yaitu "Komiknya sangat bagus, alur cerita yang jelas mengarah ke kompetensi materi yang ingin dicapai, memudahkan dalam pemahaman materi". Serta materi keanekaragaman hayati yang disajikan juga dapat memotivasi mahasiswa dan peserta didik untuk membacanya. Hal ini sesuai dengan kesan mahasiswa setelah membaca komik yaitu "Komik literasi sains ini dapat memudahkan peserta didik belajar karena dapat menarik minat baca dan mudah dipahami." Sejalan dengan Sudjana dan Rivai (2015) bahwa peranan komik dalam pengajaran adalah kemampuannya dalam meningkatkan minat belajar para peserta didik. Media komik pada materi keanekaragaman hayati di buat berdasarkan kesesuaian materi dengan kurikulum. Kurikulum yang digunakan untuk mengembangkan media komik pada materi keanekaragaman hayati ini menggunakan kurikulum 2013. Sitepu (2012) menyatakan bahwa aspek utama dalam menyusun sumber belajar seperti buku teks dan sumber belajar lainnya adalah kurikulum yang berlaku karena sasaran, tujuan materi dan metode penyajian materi terdapat pada kurikulum.

Bahasa yang digunakan dalam media komik pada materi keanekaragaman hayati ini menggunakan bahasa yang sederhana dan mudah dipahami sehingga peserta didik dapat belajar secara mandiri menggunakan komik ini. Hal ini sesuai dengan kesan mahasiswa yaitu "Media komik ini sangat cocok untuk peserta didik karena dapat meningkatkan minat untuk belajar sehingga mereka tidak bosan dengan cara belajarnya, karena, komik berbasis literasi sains ini di buat dengan penjelasan yang baik dan mudah di mengerti". Serta "komik yang dibuat bagus sehingga dapat digunakan dalam pembelajaran mandiri". Hal ini sejalan dengan Purwanto (2013) bahwa kalimat atau kata-kata dalam bahasa komik dibuat sesederhana mungkin, ringkas, jelas dan padat, sehingga mudah untuk memahami isi dari komik.

Secara keseluruhan, diperoleh skor total untuk kelima aspek penilaian adalah 3,42 dengan kategori sangat baik. Dapat disimpulkan bahwa berdasarkan hasil analisis uji coba tahap I dan tahap II secara keseluruhan media komik pada materi keanekaragaman hayati bagi siswa kelas X SMA telah berhasil dikembangkan dan berkualitas.

\section{KESIMPULAN}

Kualitas media komik pada materi keanekaragaman hayati bagi siswa kelas X SMA berada pada nilai rara-rata 3.60 dengan kategori sangat valid. Sedangkan hasil uji coba terbatas pada responden terkait komik yang dirancang mendapat nilai 3,42 dengan kategori sangat baik. Dengan demikian, dapat disimpulkan bahwa media komik pada materi keanekaragaman hayati bagi siswa kelas X SMA telah dikembangkan dengan kualitas sangat baik dan dapat diimplementasikan dalam skala luas. 


\section{DAFTAR PUSTAKA}

Arsyad, A. 2016. Media Pembelajaran. Jakarta: Raja Grafindo Persada

Fitria, A. D. 2017. "Pengembangan Media Gambar Berbasis Potensi Lokal pada Pembelajaran Materi Keanekaragaman Hayati di Kelas X SMAN 1 Pitu Riase Kab. Sidenreng Rapang". Sripsi (online). FKIP. Universitas Islam Negeri (UIN) Alaudin Makassar

Jariah, A. 2017. "Pengembangan Media Pembelajaran Berbasis Komik pada Materi Proses Pembekuan Darah Kelas XI MA Madani”. Skripsi. FKIP UIN Alauddin. Makassar

Kok-Sing Tang. 2015. "Reconceptualising Science Education Practices from New Literacies Research". Science Education International Journal 26, no. 3

Maxtuti, I.O. et al.,. 2013. "Pengembangan Komik Keanekaragaman Hayati sebagai Media Pembelajaran bagi Peserta didik SMA Kelas X". Bioedu 2, no. 2: 128-133

OECD. 2019. PISA 2018. Result Combined Executive Summaries. PISA-OECD Publishing

Purwanto, D. 2013. "Pengembangan Media Komik IPA Terpadu Tema Pencemaran Air Sebagai Media Pembelajaran untuk Siswa SMP Kelas VII". Jurnal Pendidikan Sains e-Pensa 1, no. $1: 71-76$

Puspitorini, R. et al.,. 2014. "Penggunaan Media Komik dalam Pembelajaran IPA untuk Meningkatkan Motivasi dan Hasil Belajar Kognitif dan Afektif". Cakrawala Pendidikan 33 , no. 3

Sanjaya, W. 2013. Perencanaan dan Desain Sistem Pembelajaran. Jakarta: Kencana Prenada Media Group 37-39

Sanjaya, W. 2014. Media Komunikasi Pembelajaran. Jakarta: Kencana Prenada Media Group

Sitepu. 2012. Penulisan Buku Teks Pelajaran. Bandung: PT. Remaja Rosdakarya

Sudjana, N. \& Rivai, A. 2015. Media Pengajaran. Bandung : Sinar Baru Algensindo

Sugiyono. 2019. Metode Penelitian dan Pengembangan (Research and Development). Bandung : Alfabeta

Wiedarti et al.,. 2016. Desain Induk Gerakan Literasi Sekolah. Jakarta: Diktorat Jenderal Pendidikan Dasar dan Menengah Kementerian Pendidikan dan Kebudayaan 